3. Бочелюк В. Й. Методика та організація наукових досліджень із

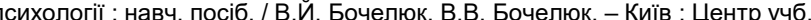
піт-ри, 2008. - 360 с

4. Максименко С. Д. Фахівця потрібно моделювати: Наукові основи готовності випускника педвузу до педагогічної діяльності / С.Д. Максименко, О.М. Пелех // Рідна школа, 1994. - № 3-4. - С. 70-78.

5. Костюк Г. С. Навчально-виховний процес і психічний розвиток особистості / Г. С. Костюк. - Київ : Рад. школа, 1996. - С. 109.

6. Леонтьев А. Н. Деятельность. Сознание. Личность / А.Н. Леонтьев. - Москва : Политиздат, 1975. - 302 с.

7. Рубинштейн С. Л. Бытие и сознание. О месте психического во всеобщей взаимосвязи явлений / С.Л. Рубинштейн. - Москва : АН СССР 1957. - C. $256-257$

\section{References}

1. Uyomov A.I. Logical foundations of the modeling method. Moscow: Mysl, 1971. $311 \mathrm{p}$
2. Philosophical encyclopedic dictionary. Inst. Of Philosophy. GS

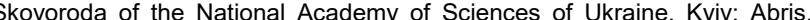
2002. $742 p$

3. Bochelyuk VY, Bochelyuk VV Methods and organization of scientific research in psychology: textbook. way. Kyiv: Center for Educational Literature, 2008. $360 \mathrm{p}$

4. Maksimenko SD Pelekh OM The specialist needs to be modeled: Scientific bases of readiness of the graduate of pedagogical high school for pedagogical activity. Native school. 1994. № 3-4. Pp.70-78.

5. Kostyuk GS Educational process and mental development of personality. Kyiv, 1996. P. 109.

6. Leontiev AN Activity. Consciousness. Personality / AN Leontiev. Moscow, 1975. 302 c

7. Rubinstein SL Being and consciousness. On the place of the mental in the universal relationship of phenomena. Moscow: AN SSSR, 1957. S. $256-257$.

Надійшла до редколегії 25.02.21

Yu. Kameniuk, PhD Stud.

Donetsk National University named after Vasily Stus, Vinnitsa, Ukraine pomnach1@gmail.com

ORCID ID 0000-0003-1017-1439

\title{
FORMATION OF A MODEL OF PATRIOTIC EDUCATION OF STUDENTS IN THE EDUCATIONAL ENVIRONMENT \\ OF THE HIGHER MILITARY EDUCATIONAL INSTITUTION
}

The article highlights the process of development and substantiation of the model of patriotic education of cadets in the educational environment of a higher military educational institution, which consists of five interrelated components: target; diagnostic; design; organizational; control and evaluation. The model was developed taking into account the requirements of system, activity, axiological, historical and diagnostic approaches. A component-by-component description of the model is made and the directions of further research are outlined. The target block determines the main purpose of patriotic education of cadets. The diagnostic block highlights the procedure for conducting a confirmatory experiment and methods of studying the level of patriotism of servicemen. The design block of the formed model is intended for creation of psychological and pedagogical conditions of formation of patriotism of cadets, and also for development of necessary tools. The result of the design block is the Target program for the formation of patriotism of servicemen "Patriot of Ukraine". The organizational unit shows the procedure for carrying out the activities of the Target Program. The control and evaluation unit of the model was formed in order to organize control, evaluation of results and further correction of the Target Program for the formation of patriotism in cadets. For a qualitative assessment of the measures, a system of criteria and indicators of patriotism has been defined and described. It is emphasized that the most important achievement of the proposed model is the integrity of information on the process of forming the patriotism of cadets. The directions of further researches, which consist in carrying out research and experimental work on formation of patriotism of servicemen and approbation of the Target program of formation of patriotism of servicemen "Patriot of Ukraine" in educational process of higher military educational institution are defined.

Keywords: model, patriotic education, system approach, activity approach, axiological approach, culturological approach, program, criteria, indicators.

УДК 159.9:316.77(043.3)

DOI: https://doi.org/10.17721/1728-2217.2021.45.33-38

Н. Рижкова, ад'юнкт наук.-організац. від-ня Військового інституту Київський національний університет імені Тараса Шевченка, Київ, Україна natalia rizhkova@ukr.net

ORCID ID 000̄0-0002-6408-355X

\section{ОБґРУНТУВАННЯ ЗМІСТУ ПРОГРАМИ ПСИХОПРОФІЛАКТИКИ СИНДРОМУ ЕМОЦІЙНОГО ВИГОРЯННЯ ВІЙСЬКОВОСЛУЖБОВЦІВ ІНЖЕНЕРНИХ ВІЙСЬК ЗБРОЙНИХ СИЛ УКРАЇНИ}

Обґрунтовано зміст авторської програми психопрофілактики синдрому емоційного вигоряння військовослужбовців інженерних військ ЗСУ. Зазначено, що величезний обсяе інженерних робіт, проведених на великих територіях і у стислі терміни, доводить, що успішне вирішення завдань з інженерного забезпечення бойових дій військ вимагає інтенсивного спілкування і викликає глибокі короткочасні емоційні переживання, які можуть спровокувати емоційне вигоряння окремих військовослужбовців. Тому у системі професійної підготовки військовослужбовця передбачено використовувати систему специфічних способів підготовки, виражених у розвитку профьесійно значущих якостей особистості, адаптації до напружених чинників професійної діяльності та неспецифічних, що характеризуються застосуванням засобів і способів саморегуляції емоційного стану профілактики виникнення емоційної напруженості. Психопрофілактика емоційного вигоряння військовослужбовия реалізується через розвиток у нього навичок саморегуляції, особистісно орієнтовану професійну освіту, а також його професійну готовність. Програма психопрофілактики емоційного вигоряння представляє собою цілісну, достатньо динамічну систему, відкриту для постійного відновлення, засновану на уявленні про розвиток військовослужбовця насамперед як індивідуальності, а потім як фахівця, професіонала із глибоким розумінням соціокультурної та освітньої ситуації. Досягнення мети можливе шляхом синтезу основних компонентів індивідуальності військовослужбовця інженерних військ: світоглядного, духовно-морального і професійного.

Ключові слова: психологічна профілактика, синдром емоційного вигоряння, військовослужбовці інженерних військ, інтенсивне спілкування, емоційні переживання, емоційна стійкість.

Постановка проблеми. На інженерні війська покладено виконання найбільш складних завдань інженерного забезпечення, які потребують використання техніки, боєприпасів і спеціальної підготовки особового складу.
Це спеціальні війська, призначені для виконання складних завдань інженерного забезпечення загальновійськових операцій (бойових дій), які вимагають спеціальної підготовки кожного військовослужбовця та використання засобів інженерного озброєння, а також для 
нанесення втрат противнику шляхом застосування інженерних боєприпасів. Величезний обсяг інженерних робіт, які проводять на великих територіях і в стислі терміни, обумовлюють необхідність в інтенсивному спілкуванні і викликають суттєві емоційні переживання, що може спровокувати емоційне вигоряння окремих військовослужбовців [10]. Отже, виникає необхідність психопрофрілактики професійно-особистісних деформацій серед військовослужбовців інженерних військ, зокрема, їхнього емоційного вигоряння.

Аналіз останніх досліджень. Найбільш розробленими аспектами проблеми синдрому емоційного вигоряння є: дослідження його сутності й структури (Є. Зеєр, В. Орел, Т. Форманюк, О. Чебикін, B. Aronson, G. Freudenberg, E. Gincberg, Chr. Maslach, D. Super, A. Pines, S.E. Jackson та ін.); засобів його профрілактики і корекції (М. Авраменко, А. Василенко, Н. Грисенко, Л. П'янківська, Т. Скорик, Л. Тищук, Я. Чаплак та ін.); з'ясування чинників його розвитку та особливостей динаміки (О. Грицук); особливостей взаємозв'язку із внутрішніми суперечностями психіки, особистісними проблемами суб'єкта (Т. Яценко) тощо. Зокрема, заслуговують на увагу психологічні аспекти виникнення, прояву та психопрофрілактики зазначеного синдрому в особливих умовах діяльності (І. Андрух, І. Ващенко, 3. Комар, Г. Ложкін, І. Приходько, Л. П'янківська, Л. Леженіна, О. Недвига та ін.) [2, 3, 5, 8-10, 13, 14]. Дослідники наголошують на тому, що цей синдром призводить до таких негативних наслідків, як: погіршення психічного і фрізичного здоров'я, зниження ефективності професійної діяльності, розвиток негативних установок стосовно свого оточення [12]

Мета дослідження - обґрунтувати зміст програми психопрофрілактики синдрому емоційного вигоряння військовослужбовців інженерних військ ЗСУ.

Виклад основного матеріалу. Для психопрофілактики емоційного вигоряння психологічна наука пропонує безліч способів, аналіз яких дозволяє класифікувати їх за двома групами: специфічні та неспецифічні. Специфрічні способи виражаються в адаптації до напружених чинників діяльності, що стимулює розвиток емоційної напруженості в особливому професійно загостреному розвитку якостей особистості: професійної спрямованості, професійної самосвідомості, психологічної культури (емпатійність, експресивні вміння, культура професійного спілкування) тощо [6]. Неспецифрічні способи характеризуються застосуванням засобів і способів саморегуляції емоційного стану, способів профрілактики і подолання стану емоційної напруженості (навчання прийомам релаксації, спеціальним фізичним і дихальним вправам, самоконтролю проявів емоційного стану, розвиток навичок знаходження і зняття "м'язових затискачів"). Цілеспрямоване використання комплексної системи специфічних і неспецифічних способів підготовки, охоплених відповідною авторською програмою, сприяє розвитку емоційної стійкості і, таким чином, попередженню емоційного вигоряння. У ній теоретичні питання формування і розвитку професійно значущих якостей, у тому числі, емоційної стійкості і навичок саморегуляції емоційних станів розглядаються на лекційних і практичних заняттях у межах таких факультативів, як: "Теорія i методика навчання і виховання", "Методи активного соціально-психологічного навчання", "Психодіагностика". Підвищення рівня емоційної стійкості здійснюється через освоєння методів саморегуляції емоційних станів у межах спецкурсу і спецпрактикумів, проведених у формі тренінгу. Методичне забезпечення процесу психопрофілактики емоційного вигоряння містить у собі такі методики: методику проведення спецкурсів, семінарів- практикумів, тренінгів із відповідних проблем; методику організації і проведення індивідуально-орієнтованої практики; методику роботи з розвитку самовдосконалення військовослужбовцями вмінь саморегуляції.

Для військовослужбовців зі службовим стажем до трьох років програмою передбачено спецкурс "Культура емоцій військовослужбовця інженерних військ". Mета курсу допомогти їм стати більш соціально адаптованими через оволодіння елементарними прийомами психічної саморегуляції, пізнання самого себе і міжособистісних відносин. Завдання курсу сприяти фрормуванню активної самосвідомості і навичок саморегуляції; особистісному зростанню; створити умови для розкриття творчого потенціалу; розвивати рефлексію; удосконалювати комунікативні вміння. Заняття за формою нагадують групові заняття соціально-психологічного тренінгу. Тривалість кожного заняття - 90 хв. Заняття проводяться у колі. Методи такі: лекція; психодіагностичні методи дослідження особистості; експресивні методи творчого самовираження в русі, рисунках, у письмових роботах; методи соціально-психологічного тренінгу, як дискусія, ігрове моделювання, імітаційні ігри. Схема заняття: формулювання теми заняття, основних цілей; психологічна розминка, що дозволяє задати темпоритм; основна частина (лекція, бесіда, система вправ); заключна частина. У процесі спецкурсу військовослужбовці розширюють уявлення про сутність понять "культура емоцій", "емоційна стійкість", "саморегуляція емоційних станів". Цей спецкурс сприяє формуванню інтелектуальної підструктури саморегуляції, пов'язаної насамперед із розвитком здатності до рефлексії, що у сполученні з результатами діагностики дозволяє реалізувати перший етап формування емоційної стійкості.

Для військовослужбовців зі службовим стажем понад три роки програмою передбачено спецпрактикум "Емоційна культура військовослужбовця інженерних військ". Мета курсу - розвиток професійно значущих якостей. Завдання курсу - усвідомлення напруженості військовоі-інженерної праці; розвиток емпатії, експресії; навичок професійного спілкування і саморегуляції в конфліктних ситуаціях. Практикум "Емоційна культура військовослужбовця інженерних військ" $\epsilon$ складовою в системі професійної підготовки. Він спрямований на профілактику і попередження дії неконструктивних механізмів у професійному спілкуванні через засвоєння прийомів саморегуляції. Курс сприяє формуванню мотиваційного та емоційно-вольового рівнів саморегуляції і $€$ однією з умов реалізації другого етапу формування емоційної стійкості. Також передбачено спецпрактикум "Способи саморегуляції емоційних станів у військово-інженерній праці" у формі тренінгу. Мета курсу - оволодіння прийомами і методами психофізіологічної саморегуляції емоційних станів. Завдання курсу - вивчення основ аутотренінгу; засвоєння прийомів саморегуляції. Спецпрактикуми дозволяють військовослужбовцям, з одного боку, оцінити їхню ефективність, а з іншого, самоствердиться у виборі способів саморегуляції. За підсумками діагностики емоційного стану військовослужбовців для тих із них, у кого найбільш виражені ознаки емоційного вигоряння, пропонується проведення індивідуальних консультацій. Консультації дозволяють реалізувати третій етап, результатом якого $€$ визначення можливостей індивідуального зростання у професійній сфрері. Критеріями оцінки ефективності програми $€$ емоційна стійкість військовослужбовців, відсутність проявів синдрому емоційного вигоряння як форми професійно особистісної деформації, сформованість прийомів саморегуляції. Показники динаміки емоційного розвитку: високий рівень емоційної стійкості; 
у ситуації фрустрації реакція за типом "із фріксацією на задоволенні потреби"; відсутність "емоційного вигоряння"; розвинені регуляторні вміння.

Отже, у системі професійної підготовки військовослужбовця інженерних військ ЗСУ необхідно приділяти спеціальну увагу психопрофрілактиці емоційного вигоряння, для чого в процесі навчання може використовуватися комплексна система специфічних і неспецифічних способів підготовки.

Розвиток навичок саморегуляції. Індивідуальні особливості саморегуляції характеризуються тим, як людина планує і програмує досягнення мети, враховує значущі зовнішні і внутрішні умови, оцінює результати і корегує своєю діяльністю. Активність суб'єкта із формулювання і досягнення мети опосередковується системою саморегуляції, яка, по суті, $\epsilon$ провідником, що пов'язує динамічні і змістовні аспекти особистості, усвідомлені і несвідомі її структури. Концепція детермінуючої ролі процесу усвідомленого регулювання, яку розробив О. Конопкін на моделі сенсомоторної діяльності, доводить, що залежність сенсомоторної діяльності людини від об'єктивних умов закономірно опосередковується процесом цілеспрямованої регуляції. Саме усвідомлене регулювання $\epsilon$, на його думку, вищою інстанцією у системі чинників, які детермінують сенсомоторну діяльність людини [7]. По суті, ототожнюються поняття саморегуляції і довільної регуляції, в основі яких перебуває усвідомленість людиною своєї діяльності, а отже, одним із проявів саморегуляції може вважатися самоусвідомлення [4]. Як зазначає О. Конопкін, психічна саморегуляція є одним із вищих рівнів регуляції активності біологічних систем, що відображають якісну специфіку реалізуючих її психічних засобів відображення і моделювання дійсності, у тому числі, рефлексію суб'єкта на самого себе, власну активність, діяльність, вчинки. У межах дослідження питань саморегуляції діяльності було виокремлено та обґрунтовано структуру системи усвідомленого цілеспрямованого регулювання діяльності.

Одну із теорій саморегуляції функціонального стану, або психічного тонусу, необхідного для оптимальної діяльності людини в конкретних умовах, висунув Г. Фрідман [17]. Він описав кілька типів саморегуляції. Перший із них здійснюється за допомогою зміни рухової активності (саморегуляція за допомогою "відреагування"). Другий тип саморегуляції реалізується із залученням додаткового припливу до мозку нервової імпульсації. Сюди можна віднести такі поширені засоби тонізації, як фрізичне навантаження, вплив на органи почуттів, рецептори шкіри (музика, холодний душ, масаж і т. п.). Ще одним універсальним і потужним засобом оптимізації функціонального стану і нормалізації вегетативних функцій в організмі $є$ короткочасні позотонічні вправи, характерною рисою яких $є$ те, що м'язи i сухожилля, які, перебуваючи в стані напруження, не скорочуються, а натягаються, підсилюючи пропріорецептивний приплив імпульсів до кори головного мозку. Поряд із зазначеними вище методами, слід згадати один із найбільш простих та ефективних - елементи дихальної гімнастики, оскільки $є$ встановленим фактом, що фаза вдиху збуджує симпатичну нервову систему, активізуючи діяльність усіх систем організму, а фаза видиху - парасимпатичну, що справляє гальмуючий вплив. Дихальна гімнастика будується на використанні різних прийомів вільного і ритмічного подиху. Дуже важливою $є$ необхідність калібрування параметрів подиху частотою серцебиття. Третій тип саморегуляції характеризується використанням умовних (звичних) сигналів, що сполучалися раніше з певним рівнем пильнування, і тому таких, що викликаються зазвичай (саморегуляція сигнальна). Четвертим типом саморегуляції слід вважати психологічну підготовку. Їй приділено важливе місце в арсеналі методів. Під нею розуміють цілеспрямоване формування індивідуальних прийомів, що забезпечують збереження заданих параметрів виконання діяльності у складних випадках. Одним із способів такої підготовки є аутогенне тренування.

Іншим напрямом у дослідженнях, що розглядає проблеми саморегуляції, $€$ саморегуляція діяльності. К. Абульханова-Славська визначає саморегуляцію як "механізм, за допомогою якого забезпечується централізуюча, напрямна та активізуюча позиція суб'єкта", виокремлюючи при цьому як одну з найважливіших характеристик саморегуляції здатність суб'єкта співвідносити власні можливості та індивідуальні особливості 3 характером розв'язуваних завдань [1]. Емоційну регуляцію професійної діяльності можна сформувати шляхом корекції способів емоційного реагування, що розкривають ставлення військовослужбовця до себе, своєї діяльності і до партнерів по цій діяльності. Було встановлено, що важливим чинником формування емоційної регуляції поведінки є досвід спілкування. Під впливом досвіду фрормуються певні ланки цього механізму, пов'язані із застосуванням рішення в емоціогенних ситуаціях. Формування і здійснення цілеспрямованої діяльності припускає як обов'язкову передумову відображення людиною зовнішніх умов у вигляді деякої суб'єктивної моделі. Вона $€$ основою як для попереднього психологічного програмування дій, так і для їхньої регуляції в процесі самої діяльності. Модель стає найважливішим та обов'язковим функціональним утворенням, повнота і точність якого багато у чому визначає ефективність діяльності та особливості її здійснення. Іншою важливою ланкою в процесі саморегуляції $€$ психологічне налаштування на роботу за певних умов. Налаштування, адекватні уявленню людини про завдання та умови майбутньої діяльності, $€$ необхідними компонентами загальної структури процесів програмування та регуляції діяльності.

Особистісно орієнтована військово-професійна освіта. На цей час у військово-професійній освіті затверджується нова парадигма - особистісно орієнтована. Метою особистісно орієнтованої військово-професійної освіти є розвиток спрямованості, компетентності, професійно важливих якостей і психофрізіологічних властивостей. Важливе значення в реалізації особистісно орієнтованої професійної освіти належить фрормуванню прийомів саморегуляції, які мають відповідати індивідуальним особливостям військовослужбовця.

Навчання дає унікальну можливість організації кооперативної діяльності. Принципово важливим $є$ положення про те, що особистісно орієнтована військовопрофесійна освіта створює умови для повноцінного і спільного розвитку всіх суб'єктів освітнього процесу [16]. Виходячи із сутності особистісно орієнтованої професійної освіти, можна визначити основний зміст психологічного супроводу військовослужбовців інженерних військ. Саме супровід зводиться до створення умов для повноцінного професійного становлення особистості, надання своєчасної допомоги і підтримки, а за необхідності до здійснення корекції професійного розвитку. Психологічний супровід полягає в наданні їм допомоги в адаптації до нових умов життєдіяльності. До технологій психологічного супроводу належать: діагностика готовності до навчально-пізнавальної діяльності, мотивів навчання, ціннісних орієнтацій, соціально-психологічних установок; допомога у розвитку навчальних вмінь і регуляції своєї життєдіяльності; психологічна підтримка у 
подоланні труднощів самостійного життя і встановленні комфортних взаємин із співслужбовцями і тими, хто навчає; корекція професійного самовизначення.

Програма психологічного супроводу професійної підготовки військовослужбовця інженерних військ має передбачати технології супроводу, спрямовані на формування навичок психологічної саморегуляції як основи розвитку емоційної стійкості. Реалізація програми психологічного супроводу дозволить забезпечити необхідний рівень професійної готовності, що $€$ однією 3 неодмінних умов ефективності професійної діяльності. К. Платонов зазначав, що професійна готовність фахівця - це суб'єктивний стан особистості, що вважає себе здатною і підготовленою до виконання відповідної професійної діяльності і прагне її виконувати [10].

Професійна готовність військовослужбовця. Провідним і найбільш складним аспектом професійної готовності військовослужбовця інженерних військ $€$ психологічна професійна готовність його психіки. Це той або інший ступінь підготовленості та налаштованості психіки, духовних сил його як фрахівця на вирішення професійних завдань, виконання своїх функціональних обов'язків, майстерність. Комунікативна готовність військовослужбовця як фахівця припускає розвиток у нього емпатійності, доброзичливості, товариськості, почуття товариства, колективізму, готовності і здатності у своїй взаємодії з колегами не створювати непотрібної напруженості у взаєминах, вмінь правильно вирішувати труднощі, що виникають, колізії у відносинах зі співслужбовцями.

У межах психогігієнічного підходу виокремлюють як значущі такі аспекти психічного здоров'я особистості: позитивне ставлення до себе; оптимальний розвиток, зростання і самоактуалізація особистості; психічна інтеграція; особиста автономія; реалістичне сприйняття оточення; вміння адекватно впливати на оточення. Більшість умов і рекомендацій з регуляції психологічних станів спрямовано на відновлення саме цих аспектів здоров'я. Психологи наполегливо рекомендують фахівцям, що піддаються емоційному вигорянню, вести щоденник. Робота ця вимагає великої внутрішньої дисципліни. Треба детально описувати щоденні події, коли і що відбулося, зазначати пов'язані із подіями відчуття. Ведення щоденника не лише допомагає проаналізувати і зрозуміти взаємозв'язок подій, глянути на них з боку, але й стимулює людину до рефлексії.

На думку О. Романової та М. Горохової, велика роль у зменшенні негативного впливу синдрому емоційного вигоряння належить насамперед самому фахівцю, який дотримується таких рекомендацій, завдяки яким він не лише зможе запобігти виникненню синдрому емоційного вигоряння, але і досягти зниження ступеня його виразності:

- визначення короткострокових і довгострокових цілей. Це не лише забезпечує зворотний зв'язок, що свідчить про те, що людина перебуває на правильному шляху, але й підвищує довгострокову мотивацію. Досягнення короткострокових цілей - це успіх, що підвищує ступінь самовиховання;

- використання "тайм-аутів". Для забезпечення психічного i фрізичного благополуччя дуже важливі "тайм-аути", тобто відпочинок від праці та інших навантажень. Іноді необхідно "втекти" від життєвих проблем і розважитися, треба знайти заняття, що було б захопливим і приємним;

- оволодіння вміннями і навичками саморегуляції. Оволодіння такими психологічними вміннями і навичками, як релаксація, ідеомоторні акти, визначення цілей і позитивне внутрішнє мовлення сприяють зниженню рівня стресу, що призводить до емоційного вигоряння;

- професійний розвиток і самовдосконалення. Одним із способів профілактики синдрому емоційного вигоряння $є$ обмін професійною інформацією з представниками інших служб. Співробітництво дає відчуття більш широкого світу, ніж той, який існує всередині окремого колективу. Для цього існують різні курси підвищення кваліфікації, усілякі професійні, неформальні об'єднання, де зустрічаються люди 3 досвідом, що працюють в інших системах, де можна поговорити, у тому числі, і на сторонні теми;

- уникнення непотрібної конкуренції. У житті дуже багато ситуацій, коли неможливо уникнути конкуренції. Але занадто вже велике прагнення до перемоги створює напруження і тривогу, робить людину занадто агресивною, що сприяє, у свою чергу, виникненню синдрому емоційного вигоряння;

- емоційне спілкування. Коли людина аналізує власні почуття і відчуття та ділиться ними з іншими, імовірність емоційного вигоряння значно знижується або цей процес не так явно виражений. Тому рекомендовано, щоб колеги у складних ситуаціях обмінювалися думками, шукали і знаходили у них професійну підтримку;

- фізичні навантаження, здоровий спосіб життя [15].

Емоціогенні форми професійної дезадаптації військовослужбовців інженерних військ (у яскраво вираженій формі це і $\epsilon$ синдромом емоційного вигоряння) $\epsilon$ характерною ознакою їхньої військової праці і водночас можуть бути проявом професійної непридатності, тому дуже важливо, щоб поза робочим часом військовослужбовець міг, одержуючи деяке фрізичне навантаження, відволіктися від роботи "і розумом, і тілом". Неправильне харчування, зловживання спиртними напоями, тютюном, зменшення або надмірне підвищення маси тіла збільшують прояв синдрому емоційного вигоряння. Якщо ж цей синдром $€$ вже невід'ємним атрибутом особистості професіонала, то виникає необхідність професійної психологічної допомоги.

Високий рівень суб'єктної усвідомленої саморегуляції $\epsilon$ суттєвою передумовою ефективного, усвідомленого контролю поведінки, можливостей компенсації нестійких емоційних станів. Становлення і розвиток до певного рівня емоційної стійкості пов'язані із фрормуванням прийомів саморегуляції, які мають відповідати індивідуальним особливостям військовослужбовця. Причому система емоційної саморегуляції напруженої діяльності стає більш диференційованою і впорядкованою, якщо умови іï розвитку спрямовано на формування встановленої послідовності і взаємозв'язку ланок цілісного процесу саморегуляції. Цілеспрямованому формуванню має передувати засвоєння військовослужбовцем загальних знань про цілісний процес емоційної саморегуляції. Емоційна регуляція службово-бойової діяльності може бути сформована шляхом корекції способів емоційного реагування, що розкривають ставлення військовослужбовця до себе, своєї діяльності і до партнерів по цій діяльності.

Підготовка військовослужбовця інженерних військ як фрахівця є процесом формування у нього достатнього для професійної діяльності рівня попередньої готовності його психіки, стійких, статичних компонентів його професійної підготовленості, у тому числі, й емоційній стійкості. Необхідною умовою професійної готовності такого фахівця $€$ психологічна готовність, що характеризується відповідним рівнем стійкості його психіки до впливу стресових обставин, адаптивності особистості, її достатньої стресозахищеності, упевненості фахівця у власних силах і можливостях, у цілому відповідним 
рівнем надійності його психіки і можливістю здійснення усвідомленої саморегуляції. Освоєння прийомів саморегуляції на етапі професійної підготовки дозволить підготувати майбутнього фахівця до вирішення проблем, що виникають у зв'язку з розвитком професійно обумовлених деформацій особистості і, зокрема, емоційного вигоряння. Проєктування моделі психолого-педагогічного супроводу припускає розгляд психологічних умов, що забезпечують ефективність цього процесу, а також методичного оснащення. Також умовами успішного становлення особистості військовослужбовця інженерних військ ЗСУ можна вважати: оволодіння нормами професійної діяльності, професійного спілкування на достатньо високому рівні професійної майстерності, розвиток професійно значущих якостей, оволодіння прийомами саморегуляції, підвищення емоційної стійкості.

Процес розвитку емоційної стійкості військовослужбовця інженерних військ як умови психопрофілактики його емоційного вигоряння припускає вивчення, визначення і розвиток його індивідуальних можливостей, допомогу йому в усвідомленні власних ресурсів, що позитивно впливає на ефективність його професійної освіти і визначає характер оволодіння спеціальністю, а надалі - професійною майстерністю. Становлення емоційної стійкості - результат не лише зовнішніх впливів, але й саморозвитку, професійного самовдосконалення. Аналіз існуючих у реальному навчально-виховному процесі способів, прийомів розвитку саморегуляції емоційного стану молодих військовослужбовців переконує в тому, що їх використовують зазвичай фрагментарно. Найчастіше на практиці декларується усвідомлення права на розкриття власної індивідуальності, але не створюються умови для цього, не завжди формується психологічний комфорт у колективі для ефективного індивідуально-орієнтованого навчання. У системі підготовки військових кадрів для інженерних військ відсутня цілісна концепція формування вмінь саморегуляції як основи попередження емоційного вигоряння. Тому у зв'язку із загальним завданням індивідуалізації професійного навчання військовослужбовців особливого значення набуває розробка моделі формування основ таких вмінь у період навчання.

3 огляду на складність, багатоаспектность феномена емоційного вигоряння і поліфакторність процесу його розвитку вважаємо, що розрізнені зусилля всіх учасників цього процесу не можуть повною мірою забезпечити повноцінну психопрофілактику емоційного вигоряння. Тому так важлива їхня професійна єдність, творча спрацьованість в процесі реалізації принципів індивідуалізації і варіативності військово-професійної освіти. Результативність розвитку рефлексії, інтеграції суб'єктів процесу розвитку емоційної стійкості найбільш яскраво проявляється під час стажування чи підвищення кваліфікації, що забезпечує поєднання теоретичної підготовки із практичною реалізацією індивідуальних вмінь і надає їм можливість повніше осмислити закономірності, етапи становлення основ саморегуляції емоційних станів. Можна вважати, що практика - це органічна частина військово-професійної підготовки, яка має бути організована як процес вирішення практикантом у реальних умовах актуальних проблем, що дозволяють кожному військовослужбовцю здійснювати самопізнання, рефлексію, особистісно-діяльнісну реалізацію сформованих вмінь саморегуляції. У процесі стажування чи підвищення кваліфікації військовослужбовці гостро усвідомлюють необхідність самовдосконалення - свідомої, цілеспрямованої, систематичної діяльності, спрямованої на розвиток сильних ланок саморегуляції емоційного стану, компенсацію слабких, на можливо більш повну самореалізацію індивідуальних потенційних можливостей у військово-професійній сфері.

Методичне забезпечення психопрофілактики емоційного вигоряння містить у собі методику проведення спецкурсів, семінарів-практикумів, тренінгів із відповідних проблем; методику організації і проведення індивідуально-орієнтованої практики; методику роботи 3 розвитку самовдосконалення військовослужбовцями вмінь саморегуляції. На основі узагальнення досвіду професійної підготовки військовослужбовців інженерних військ ЗСУ та ретроспективного аналізу власної професійної діяльності під час проходження служби у військовій частині автором визначено три етапи цього процесу. Перший етап розглядається як мотиваційноустановчий, що створює основу для подальших етапів. Військовослужбовець поглиблює уявлення про сутність понять "емоційна стійкість", "емоційне вигоряння" "саморегуляція емоційних станів". До змісту навчання включається комплекс знань про психологічні особливості військово-професійної діяльності. На основі усвідомлення діагностичних даних він пізнає індивідуальні особливості емоційної сфери. Таким чином, при успішній реалізації першого етапу відбувається усвідомлення військовослужбовцем себе як неповторної унікальної індивідуальності; у нього формується стійка мотивація на усвідомлення, засвоєння вмінь саморегуляції. При реалізації другого етапу процес співвіднесення індивідуальних можливостей із сформованою емоційною стійкістю відбувається завдяки включенню військовослужбовців у різні види індивідуально орієнтованої практики. Другий етап передбачає самооцінку військовослужбовцем індивідуальних особливостей на основі послідовного використання індивідуальних способів саморегуляції емоційних станів, прийомів попередження вигоряння у реальних умовах. Таким чином, на другому етапі військовослужбовець співвідносить інформацію про власні індивідуально-типологічні якості зі специфікою військово-професійної діяльності в інженерних військах, тобто відбувається взаємна проекція власної індивідуальності на військово-професійну діяльність і навпаки, вимог, цілей, умов діяльності на індивідуальний потенціал, набуття первісного професійного досвіду, апробація у реальній практиці індивідуальних вмінь саморегуляції, сорормованих на першому етапі. Як результат військовослужбовець починає поступово опановувати оптимальними для нього способами саморегуляції емоційних станів. У процесі здійснення третього етапу військовослужбовець або самостверджується у виборі способів саморегуляції, або розуміє, що обраний варіант необхідно модифікувати; визначає можливості індивідуального зростання у професійній сфрері. У результаті цього він вибудовує оптимальну для нього модель індивідуально-особистісного і професійного саморозвитку та самовдосконалення [16].

Висновки. Таким чином, авторська програма психопрофрілактики емоційного вигоряння представляє собою цілісну, достатньо динамічну систему, відкриту для постійного відновлення, засновану на уявленні про розвиток військовослужбовця інженерних військ ЗСУ насамперед як індивідуальності, а потім як фахівця, професіонала з глибоким розумінням соціокультурної та освітньої ситуації. Досягнення цієї мети є можливим шляхом синтезу основних компонентів індивідуальності військовослужбовця інженерних військ ЗСУ: світоглядного, духовно-морального і професійного.

Список використаної літератури

1. Абульханова-Славская К. А. Социальное мышление личности: проблемы и стратегии исследования / К. А. Абульханова-Славская // Психолог. журн., 1994. - Т. 12, № 4. - С. 39-55. 
2. Андрух І. В. Психологічні умови запобігання емоційного вигоряння оперативними співробітниками Служби безпеки України: дис. канд. психол. наук./ І. В. Андрух. - Хмельницький : Нац. акад. Держ. прикордонної служби України імені Богдана Хмельницького, 2016. - 196 с

3. Ващенко І.В. Про деякі показники емоційного вигоряння працівників ОВС / І.В.Ващенко, С. Л.Андроник // Вісн. ХНПУ імені Г.С. Сковороди. Серія: Психологія. - Харків: Вид-во ХДПУ, 2007. Вип. 23. - С. 44-52.

4. Дудяк В. Емоційне вигоряння / Дудяк В. - К. : Главник, 2007. - 126 с.

5. Зоран Комар. Психологічна стійкість воїна : підручник для військових психологів / Зоран Комар - К., 2017. - 184 с.

6. Кокун О. М. Оптимізація адаптаційних можливостей людини у психофізіологічному забезпеченні діяльності : дис... д-ра психол. наук. / Кокун О. М. - Київ : Ін-т психології ім. Г.С. Костюка АПН України, 2004. $426 \mathrm{c}$.

7. Конопкин О.А. Психологические механизмы регуляции деятельности / О. А. Конопкин. - М. : ЛЕНАНД, 2011. - 320 с

8. Леженина Л. М. Психологічні чинники емоційного вигоряння слідчих Служби безпеки України : дис... канд. психол. наук / Л. М. Леженина. - Київ : Академія управпіння МВС України, 2009. - 190 с.

9. Ложкін Г.В.Психологічне супроводження військовослужбовців у діяльності за екстремальних умов / Г. В. Ложкін. - Київ : МО України, 2003. -218 c.

10. Недвига О. В. Психологічне забезпечення професійної діяльності військовослужбовців-саперів в особливих умовах діяльності : дис. канд. психол. наук / О. В. Недвига. - Київ : Нац. ун-т оборони України імені Івана Черняховського, 2019. - 257 с.

11. Платонов К. К. Вопросы психологии труда / К. К. Платонов. М. : Медицина, 1970. - 264 с.

12. Потапчук $Є$. М. Соціально-психологічні основи збереження психічного здоров'я військовослужбовців : дис... д-ра психол. наук / Є. М. Потапчук. - Хмельницький : Нац. акад. держ. прикордонної служби України ім. Б. Хмельницького, 2004. - 365 с.

13. Приходько І. І. Психологічна безпека персоналу екстремальних видів діяльності (на прикладі військовослужбовців внутрішніх військ МВС України) : дис. ... д-ра психол. наук / І. І. Приходько. - Харків : Нац. ун-т цивільного захисту України, 2014. - 397 с.

14. П'янківська Л. В. Психологічна профрілактика синдрому "емоційного вигоряння" у курсантів вищих навчальних закладів МВС України : дис. канд. психол. наук / Л. В. П'янківська. - Київ : Нац. ун-т оборони України імені Івана Черняховського, 2019. - 18 с

15. Романова Е. С., Горохова М. Ю. Личность и эмоциональное выгорание / Е. С. Романова, М. Ю. Горохова // Вест. практич. психологии, 2004. - № 1. - С. 18-23.

16. Сидак В. С., Сафрін О. Д. Психолого-акмеологічні основи професійного та особистісного самовдосконалення співробітників правоохоронних органів України : монографія / В. С. Сидак, О. Д. Сафін. - Київ : НА СБУ, 2004. - 133 с

17. Friedman I. A. Self-efficacy and burnout in teaching: the importance of interpersonalrelations efficacy / I. A. Friedman // Social Psychology of Education. - Netherlands : Kluwer Academic Publishers, 2003. - Vol. 6. P. 191-215.

\section{References}

1. Abul'hanova-Slavskaja K.A. (1994) Social'noe myshlenie lichnosti: problemy i strategii issledovanija [Social thinking of personality: problems and research strategies]. Psihologicheskij zhurnal. T.12. №4. S.39-55 (in Russian).

2. Andrux I.V. (2016) Pcyxologichni umovy zapobigannja emocijnogo vygorannja operatyvnymy cpivrobitnykamy Cluzhby bezpeky Ukrai'ny [Psychological conditions for preventing emotional burnout by operatives of the Security Service of Ukraine]: dys. kand. pcyxol. nauk. Nacional'na akademija Derzhavnoi' prykordonnoi' cluzhby Ukrai'ny imeni Bogdana Xmel'nyc'kogo, Xmel'nyc'kyj. 196 s. (in Ukranian).
3. Vashhenko I.V. (2007) Pro dejaki pokaznyky emocijnogo vygorjannja pracivnykiv OVC [About some indicators of emotional burnout of law enforcement officers] / I.V. Vashhenko, C.L. Andronyk. Vicnyk XNPU imeni G.C. Ckovorody. Serija: Pcyxologija. Xarkiv: Vyd-vo XDPU. Vyp. 23. C. 4452 (in Ukranian).

4. Dudjak V. Emocijne vygorjannja [Emotional burnout]. K.: Glavnyk, 2007. 126 c. (in Ukranian).

5. Zoran Komar. (2017) Psyhologichna stijkist' voi'na [Psychological stability of the warrior]: pidruchnyk dlja vijs'kovyh psyhologiv. K. $184 \mathrm{~s}$. (in Ukranian).

6. Kokun O.M. (2004) Optymizacija adaptacijnyh mozhlyvostej ljudyny u psyhofiziologichnomu zabezpechenni dijal'nosti [Optimization of human adaptive capabilities in psychophysiological support of activity]: dys... d-ra psyhol. nauk. Instytut psyhologii' im. G.S. Kostjuka APN Ukrai'ny. K. 426 s. (in Ukranian)

7. Konopkin O.A. (2011) Psihologicheskie mehanizmy reguljacii dejatel'nosti [Psychological mechanisms of activity regulation]. M.: LENAND. $320 \mathrm{~s}$. (in Russian).

8. Lezhenyna L.M. (2009) Psyhologichni chynnyky emocijnogo vygorannja slidchyh Sluzhby bezpeky Ukrai'ny [Psychological factors of emotional burnout of investigators of the Security Service of Ukraine]: dys... kand. psyhol. nauk. Akademija upravlinnja MVS Ukrai'ny, K. 190 s. (in Ukranian).

9. Lozhkin G.V. (2003) Psyhologichne suprovodzhennja vijs'kovosluzhbovciv u dijal'nosti za ekstremal'nyh umov [Psychological support of servicemen in activities under extreme conditions]. K.: MOU. 218 s. (in Ukranian).

10. Nedvyga O.V. (2019) Psyhologichne zabezpechennja profesijnoi dijal'nosti vijs'kovosluzhbovciv-saperiv $v$ osoblyvyh umovah dijal'nosti [Psychological support of professional activity of servicemen-sappers in special conditions of activity]: dys. kand. psyhol. n. Nacional'nyj universytet oborony Ukrai'ny imeni Ivana Chernjahovs'kogo. K. 257 s. (in Ukranian).

11. Platonov K.K. (1970) Voprosy psihologii truda [Questions of labor psychology]. M.: Medicina. 264 s. (in Russian).

12. Potapchuk Je.M. (2004) Social'no-psyhologichni osnovy zberezhennja psyhichnogo zdorov'ja vijs'kovosluzhbovciv [Sociopsychological foundations of maintaining the mental health of servicemen] [Psychological safety of personnel of extreme types of activity (on the example of servicemen of internal troops of the Ministry of Internal Affairs of Ukraine)]: dys. dys... d-ra psyhol. nauk. Nacional'na akademija derzh. prykordonnoi' sluzhby Ukrai'ny im. B. Hmel'nyc'kogo. Hmel'nyc'kyj. 365 s. (in Ukranian).

13. Pryxod'ko I.I. (2014) Pcyxologichna bezpeka perconalu ekctremal'nyx vydiv dijal'nocti (na prykladi vijc'kovocluzhbovciv vnutrishnix vijc'k MVC Ukrai'ny): dyc. ... d-ra pcyxol. nauk. Nacional'nyj univercytet cyvil'nogo zaxyctu Ukrai'ny. Xarkiv. 397 c. (in Ukranian).

14. P'jankivs'ka L.V. (2019) Psyhologichna profilaktyka syndromu "emocijnogo vygorannja" u kursantiv vyshhyh navchal'nyh zakladiv MVS Ukrai'ny [Psychological prevention of the syndrome of "emotional burnout" in cadets of higher educational institutions of the Ministry of Internal Affairs of Ukraine]: dys. kand. pcyxol. nauk. Nacional'nyj universytet oborony Ukrai'ny imeni Ivana Chernjahovs'kogo, K. 18 s. (in Ukranian)

15. Romanova E.S., Gorohova M.Ju. (2004) Lichnost' i jemocional'noe vygoranie [Personality and burnout]. Vestnik prakticheskoj psihologii. №1. S.18-23 (in Russian).

16. Sydak V.S., Safin O.D. (2004) Psyhologo-akmeologichni osnovy profesijnogo ta osobystisnogo samovdoskonalennja spivrobitnykiv pravoohoronnyh organiv Ukrai'ny [Psychological and acmeological bases of professional and personal self-improvement of law enforcement officers of Ukraine]. Monografija. K.: NA SBU. $133 \mathrm{~s}$. (in Ukranian).

17. Friedman I.A. (2003) Self-efficacy and burnout in teaching: the importance of interpersonalrelations efficacy. Social Psychology of Education. Netherlands: Kluwer Academic Publishers. Vol. 6. P. 191-215

Надійшла до редколегії 23.02.21

\section{N. Ryzhkova, Postgraduate Stud.}

Scientific and Organizational Department of the Military Institute Taras Shevchenko National University of Kyiv, Kyiv, Ukraine natalia_rizhkova@ukr.net ORCID ID 0000-0002-6408-355X

\section{SUBSTANTIATION OF THE CONTENT OF THE PROGRAM OF PSYCHOPROPHYLAXIS OF THE EMOTIONAL BURNING SYNDROME THE SERVICE OFFICERS OF THE ENGINEERING TROOPS OF THE ARMED FORCES OF UKRAINE}

The content of the author's program of psychoprophylaxis of emotional burnout syndrome in servicemen of engineering troops of the Armed Forces of Ukraine is substantiated in the article. In particular, it is noted that the huge amount of engineering work carried out in large areas, short deadlines prove that the successful solution of engineering problems of combat operations requires intensive communication and causes deep shortterm emotional experiences, which can provoke emotional burnout of individual servicemen. Therefore, the system of professional training of servicemen is expected to use a system of specific methods of training, which are expressed in the development of professionally significant personality traits, adaptation to stressful factors of professional activity, and non-specific, characterized by the use of means and methods of emotional self-regulation. Psychoprophylaxis of emotional burnout of a serviceman is realized through the development of his skills of self-regulation, personality-oriented professional education, as well as his professional readiness. The program of psychoprophylaxis of emotional burnout is a holistic, sufficiently dynamic system, open for constant recovery, based on the idea of the development of the serviceman first as an individual and then as a specialist, a professional with a deep understanding of socio-cultural and educational situations. Achieving this goal is possible by synthesizing the main components of the personality of engineering troops serviceman: worldview, spiritual, moral and professional.

Keywords: psychological prevention, emotional burnout syndrome, servicemen of engineering troops, intensive communication, emotional experiences, emotional stability. 